\title{
Facing the climate change conundrum at the South Pole: actors' perspectives on the implications of global warming for Chilean Antarctic governance
}

\author{
Ekaterina Gladkovaa , Gustavo Blanco-Wells $\mathbb{1}^{\mathrm{b}, \mathrm{c}, \mathrm{d}}$ \& Laura Nahuelhual ${ }^{\mathrm{c}, \mathrm{e}}$ \\ aGraduate School of Social Sciences, International Development Studies, University of Amsterdam, Amsterdam, The Netherlands; \\ ${ }^{b}$ Instituto de Historia y Ciencias Sociales, Universidad Austral de Chile, Valdivia, Chile; 'Centro de Investigación en Dinámica de \\ Ecosistemas Marinos de Altas Latitudes, Valdivia, Chile; ${ }^{\mathrm{d} C e n t r o}$ de Ciencias del Clima y la Resiliencia, Valdivia, Chile; ${ }^{\text {Instituto de }}$ \\ Economía Agraria, Universidad Austral de Chile, Valdivia, Chile
}

\begin{abstract}
Antarctica is recognized as being geopolitically and scientifically important, and as one of the regions with the greatest potential to affect and be affected by global climate change. Still, little is known in practice about how climate change will be handled within the main governance framework of the continent: the Antarctic Treaty System (ATS). Using qualitative interviews, participant observations and policy document analysis, this paper explores the perspectives of Chilean scientific, political and non-governmental actors regarding the implications of climate change for the current Antarctic governance framework. Results corroborate a misalignment of the climate change agenda and the ATS, stemming from the divergent views displayed by a wide network of actors. From the interviews, two predominant visions emerge: (i) climate change as an opportunity, where actors recognize the role of Antarctica in regulating global climate and stress greater opportunities to conduct Antarctic-based climate change research, the need for strategic international collaboration, and the reinforcement of Chile's position in Antarctica through science; (ii) climate change as a burden where actors acknowledge climate change as a global problem, largely external to Antarctica, express disbelief regarding the effectiveness of local actions to tackle climate change and do not associate with climate change governance. The study concludes that climate change may become a dividing, rather than a unifying, field of action in Chilean Antarctic governance, reinforcing previously existing geopolitical tendencies.
\end{abstract}

\section{KEYWORDS}

Global commons; climate governance; Antarctic Treaty System; science-policy interface; geopolitics; polar ecosystems

\section{ABBREVIATIONS}

ASOC: Antarctic and Southern Ocean Coalition; ATCM: Antarctic Treaty Consultative Meeting; ATS Antarctic Treaty System; INACH: Instituto Antártico Chileno (Chilean Antarctic Institute); NGO: nongovernmental organization; PNACC: Plan of National

Adaptation to Climate Change; SCAR: Scientific Committee on Antarctic Research
An increasing number of studies assert that in order to maintain the integrity of the Antarctic region and improve its governance, climate change must be addressed more decisively (Hemmings et al. 2012; Young 2016). Regardless of the degree of climate change that is forecast, there is little doubt that it will act synergically with current anthropogenic pressures (e.g., globalization) on the Antarctic marine and terrestrial ecosystems, exacerbating the effects of the existing impacts (Halpern et al. 2008; Hoegh-Guldberg \& Bruno 2010; Woehler et al. 2014).

Despite the acknowledgement of Antarctica as an area of distinct concern by the Intergovernmental Panel on Climate Change as early as 2001, it took the ATS until the late 2000s to put climate change on its agenda. In 2009, at the 32nd ATCM, SCAR handed over its Antarctic climate change and environment review report, which suggested that all treaty parties commit to mitigating the emissions caused by their Antarctic operations (Clary \& Winther 2010;
Burleson \& Huang 2013). Since then, engagement with climate change governance bodies has become an integral part of SCAR's efforts to highlight the key role of Antarctic science in understanding climate change.

The underlying challenge is clear yet cumbersome: to find a mutual ground for synergy between the two global commons: Antarctica and the global climate. Although climate change is not defined as a global commons from a legal perspective, it can be analysed as such through the lenses of political theory, and anthropological and environmental studies. A number of authors in these fields consider climate change a tragedy of the commons and problematize the governance of climate from a global common perspective (Dietz et al. 2003; Engel \& Saleska 2005; Harrison \& Sundstrom 2010; Paavola 2011). The Antarctic commons, on the other hand, is a source of global knowledge, cultural heritage and readily available natural resources (Herber 2007). In terms of governance, commons management amounts to regulating

CONTACT Gustavo Blanco-Wells gblanco@uach.cl Instituto de Historia y Ciencias Sociales, Universidad Austral de Chile, Independencia 631, Valdivia, Chile; Centro de Investigación en Dinámica de Ecosistemas Marinos de Altas Latitudes, Centro de Ciencias del Clima y la Resiliencia, Campus Isla Teja, Independencia 631, Valdivia, Chile 
behaviours rather than resources or property rights (Vogler 2012). Dietz et al. (2003) connoted the potential dangers of ineffective commons governance. With the Antarctic region being a key component of the Earth system, its preservation also implies acting on climate governance. Consequently, climate governance demands attention and effort within the dynamic framework of the ATS.

Both climate and Antarctic governance are managed by an intricate mosaic of international treaties, agreements and agencies. The ATS is an evolving governance framework which "has developed in a pragmatic, flexible and, not infrequently, innovative manner" (Beeby 1991: 10) and has demonstrated precaution in handling controversial problems (e.g., territorial claims, new economic activities). It has adapted to the challenges of its time, whether environmental conundrums or conservation of mineral resources (Joyner 2011). However, steady growth in the treaty's membership base strains the existing consensus system, and ATS processes have been deemed protracted as a result of conflicting interests among actors (Vidas 2000). Disputes between claimants and non-claimants, as well as biological prospecting, the growth of tourism and the question of whaling, have been listed as potential threats to the integrity of the treaty (Joyner 2011; Lamers et al. 2012).

In the context of the global commons, such trends might prove detrimental to the environment unless effective governance instruments are firmly in place (Dietz et al. 2003). However, the Antarctic Treaty has failed to develop a legal response to emerging global problems: the last instrument added to the ATS was the Madrid Protocol in 1991 (Hemmings 2017a). Authors point at the disabling of some important functions of the ATS and its inability to catch up with current challenges-what Hemmings (2017b) has called the "hollowing" of the ATS. "Hollowing" also prompts Consultative Parties to deflect governance of local manifestations of global issues to either global regulation or market forces (Hemmings 2017b). This situation results in fractured and incoherent responses to issues such as climate change.

Various models have prescribed methods to govern climate change and climate commons. Responses range from top-down approaches (Hare et al. 2010) to unilateral and domestic arrangements (Engel \& Saleska 2005; Harrison \& Sundstrom 2010), to mechanisms not relying on the role of the state (Paavola 2011). Paavola (2011) argues that treating the climate as a common-pool resource reveals even more dilemmas in regard to climate governance. Firstly, access to greenhouse gas sinks should respond to sustainability concerns while still allowing the many competing users to enjoy their benefits. Secondly, absence of an exclusion mechanism makes climate commons particularly challenging to govern.
Despite discussions in the scientific literature about the effectiveness of other modes of climate commons governance, the prescription of top-down mechanisms has remained dominant in Antarctica. For this reason, climate change governance at the Antarctic level remains beyond the grasp of the ATS, despite climate change being gradually embedded in the research agenda.

The two distinct governance regimes of the two mutually inclusive global commons are a compelling subject for research. Young (1999) posits that the institutional interplay of governance regimes can either foster synergy or trigger adverse effects through mutual interference. Additionally, with changing environmental systems being under pressure, the political and social constellations around climate and Antarctic issues may be altered (Wehrmann 2016). Moreover, under the increasing importance of post-humanist perspectives (Glasberg 2012; Neimanis et al. 2015; Salazar 2017), the threats of climate change may transform the interactions between various actors within and beyond the ATS, as well as the status of artefacts (Avango 2016) and non-human agents in the reconfiguration of what is worth preserving in Antarctica. Considering the magnitude of what is at stake, it is imperative to find congruence between the two governance frameworks.

This paper explores the views of scientific, political and non-governmental actors regarding the position and implications of climate change within the current Antarctic governance system. As the nation closest to the continent of Antarctica ( $850 \mathrm{~km}$ away), Chile is one of the most crucial stakeholders in the Antarctic-related decision-making process, and its role in shaping the continental governance cannot be underestimated.

\section{Methods}

A case study with an actor-oriented approach (Long 2001) was used in this study because of its flexibility in exploring emergent issues and ongoing processes (Merriam \& Tisdell 2015). The study employed qualitative methods, such as semi-structured interviews, participant observations and secondary data analysis. Data were collected during four-month fieldwork from January to April 2016, in Santiago and Punta Arenas, the capital of the Magallanes and Chilean Antarctic Region, the southernmost region of the country. Data were organized around activities and discourses of key actors in relation to manifestations of climate change in Antarctica. Actors were categorized as: political actors (seven interviews conducted, approximately eight hours in total); scientific actors (13 interviews conducted, approximately 15 hours in total); and nongovernmental actors (two interviews conducted, approximately three hours in total). Participants came from a variety of backgrounds and included 
officials from the Chilean ministries of foreign affairs, environment and defence; scientists from the INACH, SCAR, the Wildlife Conservation Society, the Commission on the Conservation of Antarctic Marine Living Resources; and ASOC campaigners. The uneven distribution of interviewees was determined by logistics, as well as by the influence of ASOC on Antarctic affairs. The first interview with the NGO Wildlife Conservation Society demonstrated that a rather limited number of the Chilean-based NGOs conduct campaigns in Antarctica. Additionally, these NGOs are represented by ASOC, which determined the choice of the second NGO actor interviewee. Although the interviewee acted as a spokesperson for ASOC, the interviewee's statements are not assumed to fully represent the opinions of the organization.

Information was coded and analysed through Atlas.ti software and discussed among the team in several sessions of collective hermeneutics (Molitor 2001). For reasons of confidentiality, a simple nomenclature was adopted to differentiate between comments from different groups of key actors: (i) government actors, including the Ministry of Foreign Affairs, Ministry of Environment, INACH administration, Ministry of Defence, Ministry of Tourism (G); (ii) NGO actors (NGO); and (iii) scientific community actors (S).

\section{Results}

\section{The Chilean institutional context}

The ATS views peace, scientific research and environmental protection as the main frameworks of reference on the continent (Roura \& Bastmeijer 2007; Berkman 2010). In a bid to avoid Antarctica morphing into "the object of international discord" (Antarctic Treaty 1959: 2), the continent has been transformed into a demilitarized natural reserve and scientific hub. Several respondents referred to Article 3 in the Antarctic Treaty, an article that prescribes the promotion of collaborative scientific research, exchange of knowledge from scientific investigation and "exchange of personnel between expeditions and stations" (Antarctic Treaty 1959: 3), as particularly representative of the spirit of the treaty $(\mathrm{G} 2,3,4,5$, 6). For these aims, Chile has developed a multi-actor yet highly centralized governance regime (Fig. 1). The Ministry of Foreign Affairs has a monopoly over the coordination of Antarctic-related matters with its Antarctic Division, consisting of a small team of 10 people (G6) responsible for

centralizing Antarctic affairs and planning the management and execution of diplomatic, legal and policy issues together with relevant national and international organizations, while safeguarding the national interest in the conservation and protection of Antarctica and the sovereign rights of Chile on the Chilean Antarctic Territory. (G6)

Along with the Antarctic Division is the INACH, created in 1963 under the auspices of the Ministry of Foreign Affairs, "to streamline and facilitate planning, coordination and financing of Chilean scientific programmes in the Antarctic" (G2). INACH activities rest on three pillars: (i) improving the quality of Chilean Antarctic science; (ii) strengthening the condition of the Antarctic region; and (iii) developing social capital at a national level through cultural and

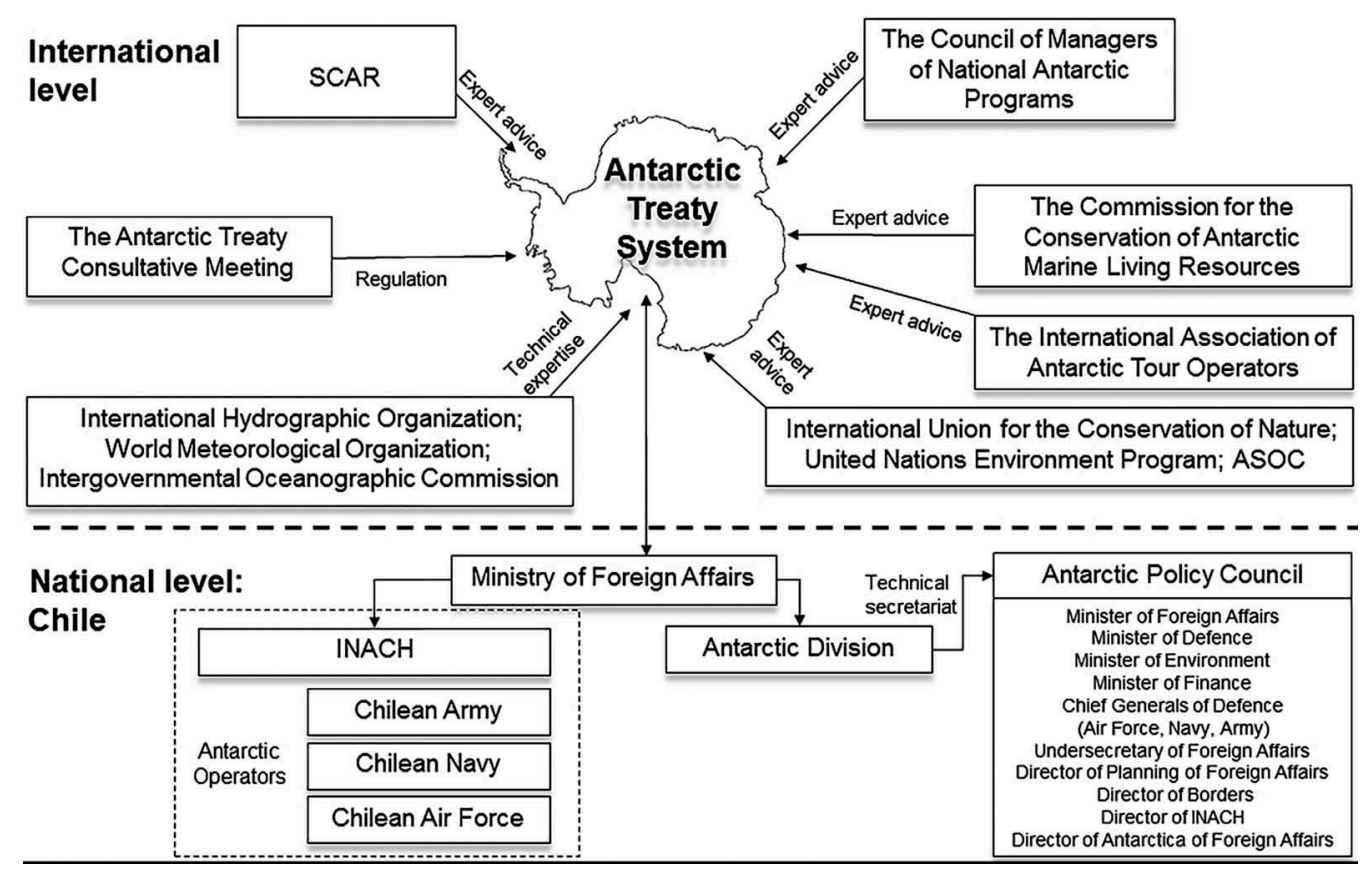

Figure 1. Scheme of governance relations between international and Chilean Antarctic actors. 
educational activities (Barticevic 2014). Also of importance for the national governance regime is the Chilean Antarctic Policy Council (Consejo de Política Antártica 2014). The Council depends on the Ministry of Foreign Affairs and is a consultative body in charge of proposing the political, scientific, economic and legal bases of national action in the Chilean Antarctic Territory (Consejo de Política Antártica 2017).

Approved in January 2017 by the Antarctic Policy Council, the Chilean National Antarctic Policy mentions the increasing relevance of climate change and policies that intend to protect the continent for "both its ecosystem fragility and its status as a natural laboratory that meets exceptional conditions for the development of science" (Consejo de Política Antártica 2017). Nevertheless, the document fails to present a specific mechanism to enforce climate protection, nor does it mention how these objectives connect to climate change policies defined by the national institution. Indeed, the rigid governance scheme led by the Ministry of Foreign Affairs sidelines the Ministry of Environment, which does not play a pivotal role in the process of Antarctic governance, as it does in the climate change governance agenda. In reviewing the links between international and national levels of decision-making, the ATS makes no mention of climate change institutions and rules, and so Antarctica seems to be outside the domains of climate change bodies. This misalignment is critically reflected in the Chilean PNACC. PNACC is a domestic policy instrument, designed in response to the objectives of the National Strategy on Climate Change, adopted in January 2006 by the Chilean Government (Ministerio del Medio Ambiente 2008). The second PNACC is near to being enacted and its final draft does not include any specific guidelines for mitigation or adaptation in Antarctica. Despite cementing mitigation policies on the national level, in terms of environmental management in Antarctica the Ministry of Environment pales beside the Ministry of Foreign Affairs, which remains a key decision-maker in the environmental management of Antarctica in Chile.

\section{State actors' appraisal of the status of climate change within ATS}

The narratives from state actors corroborate the misalignment between climate change and ATS governance regimes and agendas in Chile: "the Ministry of Environment does not have much to do with Antarctic issues. Even though the Ministry of Environment attends those meetings, they do not participate much. It is our work in progress to increase their involvement" (G6). This statement provides insight into the first rupture of dialogue among
Antarctic actors. Some interviewees assumed that "the ATCM has very little to do with climate change. Antarctica is no-man's land so the ATCM is the body that administrates the continent" (G2) and "in case of climate change $[\ldots]$ the solutions are global and not specific to the Antarctic" (G6).

Despite these claims, climate research has been an indelible part of the Chilean Antarctic mission (G5). However, national policy has only recently reflected the urgency of climate change. Although Chilean ministry officials trumpeted the government's Antarctic Strategic Plan 2015-19 (Consejo de Política Antártica 2014) and emphasized that the INACH would lead climate change research, the plan is infused with the sentiment of exerting Chilean leverage over the Treaty as well as enhancing operational capabilities for conducting science in Antarctica. Main strategic goals include: increasing Chilean participation in ATS; boosting the profile of the Magallanes region as a gateway to Antarctica; promoting Antarctic science; and strengthening logistical capacity of the Chilean state in Antarctica (Barticevic 2014). Chile hosted the 39th ATCM in May 2016. During this event, the Minister of Foreign Affairs of Chile, Heraldo Muñoz, stressed the position of the country in the ATS, and highlighted future plans and endeavours. The speech was dominated by ideas of strengthening the position of Chile "as a country with polar projection" with the policy motto of "a clean, but useful Antarctica" (Ministerio de Relaciones Exteriores 2016). The importance of geopolitical interests was also reflected in some of the interviews: "we want to have a voice in Antarctic scientific development and science enables us to have more influence and greater power" (G5). Governing the Antarctic morphs into an initiative to protect national interests within the international community. In this context, the approach to climate change is tinged by pragmatism:

It is easier for scientists to convince the government
they want to study the Antarctic because climate
change may affect their economies. Countries do
not think much of Antarctic climate change; they
are thinking of money. But if they see that climate
change will affect their economy, then they will
invest more in science. (G2)

This rationale is used to explain a recent surge in Antarctic Treaty membership, as the Czech Republic, Malaysia, Portugal, Colombia and Venezuela have committed to conducting research on the frozen continent. While some authors (Salazar 2015) view the elasticity of the Treaty as controversial and call for more effective regulation, the Chilean government welcomed expansion of the Treaty because of the possibility of more robust cooperation:

You know that there are 29 countries that carry out scientific programmes in the Antarctic-how to 
create multinational programmes that can address climate change, collaborate in logistics and monitor greater areas of the continent? It entails financial investments and greater international cooperation. [...] Chile in particular has been collaborating with 21 countries. Being the gateway to the Antarctic, Chile attracts other countries for cooperation. Recently there has been growing interest from Asian countries. Today, more than ever, international cooperation works in favour of international governance. (G5)

In May 2017, a state visit to China by Chilean president Michelle Bachelet became emblematic of a surging interest in bilateral cooperation on a variety of issues, including joint Antarctic research expeditions.

\section{The view of Chilean Antarctic scientists}

The majority of scientific respondents recognized the strategic importance of the region for the government and global climate studies. However, the scientists clearly identified institutional obstacles to accomplishing their missions while they are simultaneously under pressure to properly respond to increasing national and international demands for knowledge. For instance, the need for long-term monitoring projects was clearly stated: "gathering data just once a year is not enough to study global change" (S1). Insufficiency of information presents a particular disadvantage for climate monitoring, as climate change does not manifest itself uniformly in different parts of Antarctica, which complicates the process of drawing conclusions at this stage. This problem is aggravated by the fact that international consensus on climate change partly relies on data from the Antarctic Peninsula, and some scientists have flagged potential problems with this research site. Scientists also confirmed that project proposals are more likely to be realized if they feature ideas for international cooperation and can be conducted in collaboration with other Antarctic actors. It is clear that scientists are incentivized to forge friendly ties with their international counterparts to pave the way for successful joint research missions.

Scientific actors attested to the difficulty of coordinating international collaboration, pointing out that each country has its own agenda and "runs its own show in Antarctica” (S4). Furthermore,

\footnotetext{
for are a lot of countries in the ATS scientists there is always interest to collaborate, see what equipment other nations have, study their approach to things. But the political aspect clashes with it. For example, Chile and Argentina are so close but we do not collaborate much because we have the same interest: to mark our position in Antarctica. (S8)
}

These power dynamics preclude the government from crafting more successful and inclusive environmental policies, harmonious with the Antarctic ecosystem. Moreover, they drive a wedge between science and politics, pushing them further apart. The same issue applied to the international realm of Antarctic governance, in relation to the role of SCAR:

SCAR cannot tell policy-makers what to do; they keep out of the hassle on political-based issues and focus on evidence-based science. They may suggest taking that advice into consideration if policies that are being developed touch upon some areas of SCAR research. (S3)

Seeing science as subservient to politics, scientific respondents were willing to switch to a policyfriendly track provided that the government takes initiative to set research priorities. At the same time, the mapping of priorities was seen as a flawed endeavour: "science is managed by bureaucrats who cannot set their priorities straight. We do science for the sake of doing science but with scarce resources we need to have priorities, for the development of the country, institution or university" (S2). This misalignment of science and politics was also reflected in the scientific account of the overall absence of a strategy for climate change, despite aforementioned government plans stating the contrary: "there is not even a strategy to address climate change" (S4). However, as the matter narrows down to mitigation practices, scientists should individually and collectively undertake actions to "reduce the human footprint" (S4).

According to the scientists, this lack of strategy correlated directly with the perception of climate change as an external issue that did not originate in Antarctica (S7). The externality of climate change has taken its toll on the process of assigning value to the Antarctic territory by scientists:

I personally am very considerate of [the values] of the Antarctic environment. I try to always stick to the same path not to disturb [the species] in the surrounding areas. Obviously, not all my colleagues do the same. They are there to take advantage of the system to advance their research, to benefit from it to accomplish their scientific mission. We need more accountability mechanisms [to make sure they comply with regulations] and more evaluations on what the capacity of the ecosystem is and how much research it can withstand. (S12)

The scientific vision is conflicted. On one hand, scientific actors saw the expansion of research activities as integral to advance climate change-related policies at the government level. However, as climate change gains firm grounding in the research agenda, concerns about the impact of research projects on the Antarctic ecosystem are also increasing. In the Chilean context, this aspect clashes with the aspirations of scientists to advance their careers and the lack of priority-setting from government actors. It 
also leads to a situation where the final product of research undermines the importance of how the research was conducted. On the other hand, scientific actors resisted categorizing themselves as firmly embedded in the governance process. The importance of research lessened when considering neglect from government actors and the marginalized role of scientists in governance.

\section{Non-governmental actors}

In the realm of NGOs, ASOC was chosen for this research because of the uniqueness of its mission and its immediate connection with Antarctica. Founded in 1978, ASOC is the only NGO working full-time to preserve the Antarctic continent and its surrounding Southern Ocean. As a coalition of over 30 NGOs interested in Antarctic environmental protection, ASOC represents the environmental community at Antarctic governance meetings and works to promote important Antarctic conservation goals.

Occupying the role of invited experts, NGOs are an external body and constitute a kind of buffer between the different ATS parties. This allows them to present their agendas and shift the dynamics of relationships within the treaty system. It has been claimed that NGOs helped draw public attention to the effects of climate change in Antarctica (Cohen 2011) and mobilized Treaty stakeholders to weave this issue into the fabric of annual meetings. Overall, NGO actors pointed at gaps in the engagement with climate change on the Treaty level:

People are working on it, but it's a marginalized issue, which seems weird because Antarctica is emblematic of global climate change. We see it happening-the scientists are vocal spokespeople for it but the ATS wants to put it over to a very slowmoving international side. (NGO1)

Not only does this assertion signal the conspicuous absence of a positioned governance system, it also validates the previously discussed idea of scientists having an inferior role in the Antarctic Treaty framework: "scientists might think the knowledge is for the world but the reason why it's funded by national programmes is that the Antarctic knowledge makes the state more powerful" (NGO1). Therefore, the governance equilibrium shifts towards government actors who, as it was shown before, are reluctant to see beyond climate change research and frame the issue in support of various national ideological projects.

NGO actors were also not particularly hopeful about climate change inclusion at the Treaty level. Under the pretext of the futility of actions initiated in Antarctica, they opted for letting "the global community iron out the big story" (NGO1). Antarctica was only perceived as a platform where actors can lead by demonstrating an example of environmentally conscious behaviour.

As a result, strategies to tackle climate change from the NGO perspective rest on three pillars: reduction of greenhouse gas emissions; implementation of climate adaptation strategies; and climate science boost. The first pillar involves slashing carbon emissions through energy efficiency measures:

There are a lot of countries in the ATS doing great things when they build new bases. Belgium was running one of its stations on renewable energy and one of the new UK stations is amazing, with solar and wind power; it is a futuristic model for what is possible. But it does not negate the fact that going to the Antarctic is one of the most carbon intensive things one can do because everything needs to come with you to sustain your life.(NGO1)

Secondly, NGO actors agree that climate change impacts should be taken into account during management decisions about fisheries, protected areas and ecosystem resilience build-up: "the protected areas system is very good and very intelligently managed, there is international cooperation ... it does not mean it is always conflict-free, there are debates, discussions, blocking but it turns out pretty well" (NGO1). Lastly, while recognizing flaws in the channels of scientific communication, NGO actors stressed the importance of streamlined research work in Antarctica for more effective climate change governance administration at the international level.

While all the above-mentioned measures are crucial for addressing climate change, governance process extends beyond reduction of greenhouse gas emissions, implementation of climate adaptation strategies and boosting climate science. Unlike other actors, NGO stakeholders observed the possibility of global warming bringing further issues of resource access and conservation to the fore:

I am interested to see how this renewable energy transition that I feel has kick-started it is going to protect the Antarctic because there is always this spectre of mining or extracting resources and if we can advocate for world energy systems to transition to renewable energy before we have to raise that question, it'll help. (NGO1)

It is important to state that from the perspective of the NGO representative, preservation of Antarctica in a climate change scenario is not the problem of a specific country, such as Chile; rather an issue on a global scale that requires coordinated collaborative action of multiple, international stakeholders.

\section{Discussion and conclusion}

By the end of the past decade, climate change was finally accepted as an "Antarctic issue", reflected by the intention "to work along [work together towards 
a common goal] to better understand changes to the Earth's climate and actively seek ways to address the effects of climate and environmental change on the Antarctic environment and dependent and associated ecosystems" (Comba 2013: 313). Yet "working along" has proved to be a challenging task, and success is still ahead. Exercising the possibility of integration of climate change into the ATS regime, this research explored visions of scientific, political and non-governmental actors in Chile regarding the topic in question. Our aim was not to project the Chilean case on the rest of the ATS, but rather to provide insight into the complexity of politicizing global warming in the context of the global commons and interlocked national agendas.

The current climate strategy at the Antarctic Treaty level is the product of scientific knowledge and is an integral part of the Antarctic governance framework. Not only does science validate governance decisions, it provides a governance framework itself (O'Reilly 2017). However, generation of the above-mentioned knowledge also takes place in the context of climate change, which, as it was determined, takes its toll on the Antarctic ecosystem. The global commons vicious cycle conundrum challenges the treaty system, with Antarctic stakeholders, in theory, having to work on conducting research, keeping the global climate system in check and ensuring that knowledge production practices do not increase ecosystem vulnerability.

Our results show the challenge of finding synergy between the two commons. Chile has long been an active participant in the ATS and displays a formidable yet highly hierarchical governance structure for the task. However, climate change governance regimes and processes are still in their infancy, although evolving rapidly. In synthesis, for the Chilean actors involved, the space for convergence of the two global commons appears to be tightly connected to the role of science as a mediator among governance regimes. Yet for the ATS, science has acquired an additional geopolitical meaning, whereas for the climate change agenda the practice of science can provoke negative externalities that must be handled within the ATS. Institutional misalignment is easily observable, and, in the context of this divide, science seems to arise as the bridge between the two governance agendas while also constituting a governance framework itself. There are two further dimensions from which we can examine Chilean actors' perspective on Antarctic climate governance.

The first is climate change as an opportunity. All actors saw the governance climate change agenda as timely. However, each actor was motivated by selfinterest, which resulted in sometimes contradictory, sometimes competing, visions of opportunity. For instance, cooperation was viewed solely as a pathway to conduct research in a more efficient and adroit manner. As a result, Antarctica is not perceived as "a site of contestation and reconfiguration of ways of thinking and making decisions about climate change" (Beck 2010: 9). Instead, climate change discourse favouring the expansion of scientific activity is actively perpetuated, and governments respond to this discourse by incorporating it into their paradigm of interests, which is preoccupied with preserving their territorial claim and having political clout in Antarctica. Political actors respond to climate change with a set of discrete local mitigation measures, while seeing climate change research as a geopolitical exercise, and climate change knowledge as a product of "the struggles, confrontations and tactics of power" (Shadian \& Tennberg 2009: 189).

Chilean scientific actors, while enjoying the opportunity to advance their careers, lament their lack of opportunity to engage in the governance process. According to ethnographic research (O'Reilly 2017), scientists come across as "arbiters" and agents of authority over environmental management and governance arrangements. However, some of the institutionalized practices of the Chilean Antarctic governance do not empower scientists to realize their potential in these matters. Additionally, they fail to recognize science as pivotal for strengthening the legal regime in Antarctica, and, instead of being agents of governance, scientists focus primarily on their career development. Finally, non-governmental actors venture to politicize climate change in Antarctica, while advocating for more mitigation and adaptation measures locally, but do not step beyond these policies.

The second dimension is climate change as a burden. Scientific and NGO actors also perceived climate change governance agenda in terms of burden. Ambition to expand research activities provokes the dilemma that research itself may contribute to environmental degradation (Pertierra et al. 2013). Antarctica has long been considered "a salient symbol of surviving wilderness” (Stokke \& Vidas 1996: 5), an idea that invokes a balance between the effects of exploring and researching and the value of protecting it from impacts (Pertierra et al. 2013).

It is evident that the discourses of Chilean actors engaged in the governance process do not overlap. While actors might view climate change as an opportunity and/or burden, their interpretation of these agendas is distinctly different. Additionally, the proponents of more efficient governance schemes see coordination between actors as a prerequisite (Tin et al. 2014). Coordination is encapsulated by compatible goals (Tin et al. 2014), and the discourse divergence drives the actors' goals further apart. 
Moreover, climate change is potent enough to alter the values of the ATS (Wehrmann 2016). Considering the growing importance of global forces in Antarctica, it is possible to observe a shift from scientific cooperation to commercial pressure as the dominant policy force in the region. Hemmings (2007) posits that "[t]he Antarctic system will not collapse tomorrow but it does appear to be in relative decline, and power is shifting from states to non-state entities, and particularly to commercial interests." Zarankin \& Salerno (2014:117) remind us that "Antarctica's present distinctive features are nothing but a product of the historical strategies defining the human expansion over and the interaction with the continent." In spite of these transformations, Chilean actors have not yet developed mechanisms to address climate change in Antarctica. Since the issue of climate change entered the Antarctic Treaty agenda in the mid-2000s after purposeful reluctance to address it (Chaturvedi 2012), actors have been engaging with the physical changes catalysed by global warming, rather than with the political and legal regime quandaries (Davis 2014). This apathy maintains the status quo (Tin et al. 2014), entrenching the existing sovereign claims and nationalistic imaginations on the continent. However, climate change is an assertive force that calls into question the viability of the ATS in its current state (Tin et al. 2014), and acknowledging this requires stronger cooperation and dismissal of geopolitical concerns.

Considering this rich tapestry of opinions, approaches and visions, the Chilean case can be classified neither as synergy nor as interference (sensu Young 1999). Instead, Chile provides an example of institutional misalignment that results in the current inability to converge the ATS and climate change governance. As actors demonstrate different degrees of engagement (Treml et al. 2015) with climate change matters and different approaches to its interpretation, the issue becomes divisive.

Having taken into account these findings, we can chart two paths for future research and analysis. The first might explore the specific intersections-actors, policies and mechanisms-between governance regimes of the two global commons, both at the international and national levels, in a comparative perspective. The second path suggests taking an ethnographic perspective to identify current practices and socio-material arrangements by which different actors establish mechanisms of compliance or noncompliance with existing governance agreements. It can be concluded that the potential for alignment between the ATS and climate change governance in Chile is still rather low because of the lack of a unifying vision between actors regarding what climate change means for Antarctic governance and vice versa. However, being confronted by the global menace of a warming planet, Antarctic actors must create local responses to the challenge of climate change, thus opening the possibility of Antarctic climate change governance. It begs the question whether the ATS parties, including Chile and its different actors, are prepared to concede to this compromise for the greater good of the planet and environmental protection of the continent.

\section{Disclosure statement}

No potential conflict of interest was reported by the authors.

\section{Funding}

This work was supported and funded by the National Commission of Scientific and Technological Investigation of Chile through the Fondo de Financiamiento de Centros de Investigación en Áreas Prioritarias (FONDAP) programme Research Center: Dynamics of High Latitude Marine Ecosystems (grant no. 15150003) and the Climate and Resilience Research Center (grant no. 15110009).

\section{ORCID}

Gustavo Blanco-Wells (D) http://orcid.org/0000-0002-49803424

\section{References}

Antarctic Treaty 1959. Accessed on the internet at http:// www.ats.aq/documents/ats/treaty_original.pdf on 28 October 2016.

Avango D. 2016. acting artifacts: on the meanings of material culture in Antarctica. In P. Roberts et al. (eds.): Antarctica and the humanities. Pp. 159-179. London: Palgrave Macmillan.

Barticevic E. 2014. INACH: boosting Chilean national Antarctic science for 50 years. In R. Canales. (ed.): Ilaia. Advances in Chilean Antarctic science. Pp. 35-37. Punta Arenas: La Prensa Austral.

Beck U. 2010. Climate for change, or how to create a green modernity? Theory, Culture \& Society 27, 254-266.

Beeby C.D. 1991. The Antarctic Treaty System: goals, performance and impact. In A. Jørgensen-Dahl et al. (eds.): The Antarctic Treaty System in world politics. Pp. 4-21. London: Macmillan/Frijtjof Nansen Institute.

Berkman P. 2010. Common interests in the international space of Antarctica. Polar Record 46, 7-9.

Burleson E. \& Huang J. 2013. Antarctica and climate change. In R.S. Abate et al. (eds.): Ocean and coastal law in the climate change context: domestic and international regulatory challenges. Oxford: Oxford University Press.

Chaturvedi S. 2012. The Antarctic 'climate security' dilemma and the future of Antarctic governance. In A. D. Hemmings et al. (eds.): Antarctic security in the twenty-first century: legal and policy perspectives. Pp. 257-281. London: Routledge.

Clary D. \& Winther J. 2010. Report on implications of climate change for Antarctic management and governance. Co-chairs' executive summary with advice for 
actions. Paper presented at XXXIII Antarctic Treaty Consultative Meeting, ATCM 4, CEP 9a, 9 April 2010, Svolvaer, Norway.

Cohen H. 2011. Public participation in Antarctica: the role of non-governmental and intergovernmental organizations. In P.A. Berkman et al. (eds.): Science diplomacy. Antarctica, science, and the governance of international spaces. Pp. 271-277. Washington, D.C.: Smithsonian Institution Scholarly Press.

Comba D. 2013. An analysis of the impacts of climate change for management and governance of the Antarctic region. In W. Leal Filho. (ed.): Climate change and disaster risk management. Pp. 311-320. New York: Springer.

Consejo de Política Antártica 2014. Plan Estratégico Antártico 2015-19. (Antarctic Strategic Plan 2015-19.) Punta Arenas: Antarctic Policy Council.

Consejo de Política Antártica 2017. Política Antártica Nacional 2017. (National Antarctic Policy.) Santiago: Antarctic Policy Council. Accessed on the internet at http://www.minrel.gob.cl/minrel/site/artic/20121010/ asocfile/20121010172919/pol_tica_ant__rtica_nacio nal_2017.pdf on 20 May 2017.

Davis R.A. 2014. The durability of the 'Antarctic Model' and Southern Ocean governance. In T. Stephen \& D. Vander-Zwaag (eds.): Polar oceans governance in an era of environmental change. Pp. 287-307. Cheltenham: Edward Elgar.

Dietz T., Ostrom E. \& Stern P.C. 2003. The struggle to govern the commons. Science 302, 1907-1912.

Engel K. \& Saleska S. 2005. Subglobal regulation of the global commons: the case of climate change. Ecology Law Quarterly 32, 183-233.

Glasberg E. 2012. Antarctica as cultural critique: the gendered politics of scientific exploration and climate change. New York: Palgrave Macmillan.

Halpern B.S., Walbridge S., Selkoe K.A., Kappel C.V., Micheli F., d'Agrosa C., Bruno J., Casey K., Ebert C., Fox H., Fujita R., Heinemann D., Lenihan H., Madin E., Perry M., Selig E., Spalding M., Steneck R. \& Watson R. 2008. A global map of human impact on marine ecosystems. Science 319, 948-952.

Hare W., Stockwell C., Flachsland C. \& Oberthür C. 2010. The architecture of the global climate regime: a topdown perspective. Climate Policy 10, 600-614.

Harrison K. \& Sundstrom L.M. 2010. Global commons, domestic decisions: the comparative politics of climate change. Cambridge: MIT press.

Hemmings A. 2007. Globalisation's cold genius and the ending of Antarctic isolation. In L. Kriwoken et al. (eds.): Looking south: Australia's Antarctic agenda. Pp. 176-191. Sidney: Federation Press.

Hemmings A. 2017a. Antarctic politics in a transforming global geopolitics. In K. Dodds et al. (eds.): Handbook on the politics of Antarctica. Pp. 507-522. Cheltenham: Edward Elgar.

Hemmings A. 2017b. The hollowing of Antarctic governance. In P. Goel et al. (eds.): Science and geopolitics of the white world: Arctic-Antarctic-Himalaya. Pp. 17-31. New Delhi: Springer.

Hemmings A., Rothwell D. \& Scott K. 2012. Antarctic security in the twenty-first century: legal and policy perspectives. New York: Routledge.

Herber B. 2007. Protecting the Antarctic commons: problems of economic efficiency. Tucson: Udall Center for Studies in Public Policy, University of Arizona.
Hoegh-Guldberg O. \& Bruno J.F. 2010. The impact of climate change on the world's marine ecosystems. Science 328, 1523-1528.

Joyner C. 2011. Potential challenges to the Antarctic Treaty. In P. Berkman et al. (eds.): Science diplomacy: Antarctica, science, and the governance of international spaces. Pp. 97-102. Washington D.C.: Smithsonian Institution Scholarly Press.

Lamers M., Liggett D. \& Amelung B. 2012. Strategic challenges of tourism development and governance in Antarctica: taking stock and moving forward. Polar Research 31, article no. 17219, doi: 10.3402/polar.v31i0.17219.

Long N. 2001. Development sociology: actor perspectives. London: Routledge.

Merriam S. \& Tisdell E. 2015. Qualitative research: a guide to design and implementation. San Francisco: Jossey-Bass.

Ministerio de Relaciones Exteriores. 2016. Statement by the Minister of Foreign Affairs of Chile, Heraldo Muñoz at the Opening Ceremony of the XXXIX Antarctic Treaty Consultative Meeting. Accessed on the internet at http:// atcm39chile.gov.cl/2016/05/statement-by-the-ministerof-foreign-affairs-of-chile-heraldo-munoz-at-the-open ing-ceremony-of-the-xxxix-antarctic-treaty-consultativemeeting/ on 1 October 2016.

Ministerio del Medio Ambiente. 2008. Plan de acción nacional de cambio climático 2008-2012 (PANCC). (National climate change action plan, 2008-2012 [PANCC].) Accessed on the internet at http://www.mma.gob.cl/ 1304/w3-article-54787.html on 10 April 2017.

Molitor M. 2001. Sobre la hermenéutica colectiva. (On collective hermeneutics.) Revista Austral de Ciencias Sociales 5, 3-14.

Neimanis A., Åsberg C. \& Hedrén J. 2015. Four problems, four directions for environmental humanities: toward critical posthumanities for the Anthropocene. Ethics \& the Environment 20, 67-97.

O'Reilly J. 2017. The technocratic Antarctic: an ethnography of scientific expertise and environmental governance. Ithaca: Cornell University Press.

Paavola J. 2011. Climate change: the ultimate 'Tragedy of the Commons'? In D.H. Cole \& E. Ostrom (eds.): Property in land and other resources. Pp. 417-434. Cambridge, MA: Lincoln Institute of Land Policy.

Pertierra L.R., Hughes K.A., Benayas J., Justel A. \& Quesada A. 2013. Environmental management of a scientific field camp in maritime Antarctica: reconciling research impacts with conservation goals in remote icefree areas. Antarctic Science 25, 307-317.

Roura R. \& Bastmeijer K. 2007. Environmental impact assessment in Antarctica. In K. Bastmeijer (ed.): Theory and practice of transboundary environmental impact assessment. Pp. 175-219. Leiden: Brill/Martinus Nijhoff Publishers.

Salazar J. 2015. Anticipating Antarctica in the 21st century: a view from the social sciences. In R. Canales (ed.): Ilaia. Advances in Chilean Antarctic science. Pp. 36-39. Punta Arenas: La Prensa Austral.

Salazar J.F. 2017. Speculative fabulation: researching worlds to come in Antarctica. In J.F. Salazar et al. (eds.): Anthropologies and futures: researching emerging and uncertain worlds. Pp. 151-170. London: Bloomsbury.

Shadian J. \& Tennberg M. 2009. Legacies and change in polar science: historical, legal and political reflections on the International Polar Year. Surrey: Ashgate Press.

Stokke O. \& Vidas D. 1996. Governing the Antarctic: the effectiveness and legitimacy of the Antarctic Treaty System. Cambridge: Cambridge University Press. 
Tin T., Liggett D., Maher P. \& Lamers M. 2014. Antarctic futures: human engagement with the Antarctic environment. Dordrecht: Springer.

Treml E.A., Fidelman P.I.J., Kininmonth S., Ekstrom J. A. \& Bodin Ö. 2015. Analyzing the (mis)fit between the institutional and ecological networks of the IndoWest Pacific. Global Environmental Change 31, 263271.

Vidas D. 2000. Implementing the environmental protection regime for the Antarctic. Dordrecht: Springer.

Vogler J. 2012. Global commons revisited. Global Policy 3, 61-71.

Wehrmann D. 2016. The polar regions as "barometers" in the Anthropocene: towards a new significance of non- state actors in international cooperation? The Polar Journal 6, 379-397.

Woehler E., Ainley D. \& Jabour J. 2014. Human impacts to Antarctic wildlife: predictions and speculations for 2060. In T. Tin et al. (eds.): Antarctic futures: human engagement with the Antarctic environment. Pp. 27-60. Dordrecht: Springer. Young O. 1999. The interplay of global and polar regimes. Polar Research 18, 397-402.

Young O. 2016. Governing the antipodes: international cooperation in Antarctica and the Arctic. Polar Record 52, 230-238.

Zarankin A. \& Salerno A.M. 2014. The "wild" continent? Some discussions on the Anthropocene in Antarctica. Journal of Contemporary Archaeology 1, 75-134. 